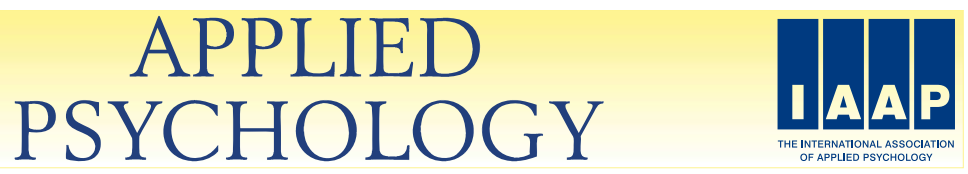

APPLIED PSYCHOLOGY: AN INTERNATIONAL REVIEW, 2010, 59 (2), 296-317 doi: 10.1111/j.1464-0597.2009.00391.x

\title{
Unemployed Individuals' Work Values and Job Flexibility: An Explanation from Expectancy-Value Theory and Self-Determination Theory
}

\author{
Anja Van den Broeck* \\ Catholic University of Leuven, Belgium \\ Maarten Vansteenkiste \\ Ghent University, Belgium \\ Willy Lens and Hans De Witte \\ Catholic University of Leuven, Belgium
}

\begin{abstract}
Changes in the contemporary labour market have resulted in an increasing demand for flexibility in the work context. The present research examines the associations between unemployed individuals' work values and their attitudes towards job flexibility. Consistent with Expectancy-Value Theory, results showed that the general concept of employment value was positively related to all measured types of flexibility, that is, training flexibility, pay flexibility, the flexibility to accept an undemanding job, and the flexibility to accept a job for which one is over-qualified. In line with Self-Determination Theory, holding an intrinsic work value orientation related positively to training and pay flexibility, whereas extrinsic work value orientation was negatively related to these two types of flexibility. Overall, these results indicate that not only the degree of employment value but also the content of unemployed individuals' work value orientations matter in understanding their job flexibility.
\end{abstract}

L'évolution actuelle du marché de l'emploi a provoqué une demande croissante de flexibilité dans le domaine du travail. On étudie dans cette recherche les liens qui existent entre les valeurs professionnelles de chômeurs et leurs attitudes envers la flexibilité. Dans la ligne de la théorie expectation-valence, les résultats montrent que le concept général de valence de l'emploi est relié positivement à toutes les mesures de la flexibilité, c'est-à-dire la flexibilité de la formation, du

* Address for correspondence: Anja Van den Broeck, Tiensestraat 102, PO Box: 03716, 3000 Leuven, Belgium. Email: Anja.VandenBroeck@psy.kuleuven.be

The first author's contribution was supported by a grant from the Fund for Scientific Research Flanders (FWO-Vlaanderen). We would like to thank Nele De Cuyper for her constructive comments on this paper.

(C) 2009 The Authors. Journal compilation (C) 2009 International Association of Applied Psychology. Published by Blackwell Publishing, 9600 Garsington Road, Oxford OX4 2DQ, UK and 350 Main Street, Malden, MA 02148, USA. 
salaire et de l'acceptation d'un poste sans intérêt ou sous-qualifié. En accord avec la théorie de l'autodétermination, le fait d'accorder une valeur intrinsèque au travail entretient une corrélation positive avec la flexibilité de la formation et du salaire, tandis que la valeur extrinsèque est en relation négative avec ces deux aspects de la flexibilité. En somme, ces résultats indiquent que chez les chômeurs non seulement le niveau de la valence de l'emploi, mais aussi le contenu des valeurs relatives au travail permettent de comprendre leur flexibilité.

\section{INTRODUCTION}

Many researchers have suggested that the labour market has changed profoundly in recent decades (e.g. Brewster, Mayne, \& Tregaskis, 1997). Globalisation and growing international competition have created an economic context in which flexibility occupies a prominent place. Whereas "productivity" was the main concern in the 1970s and quality management was of primary interest in the 1980s, being able to respond flexibly to increasing and fast-changing customer needs has become the primary criterion for economic survival since the 1990s (Aggarwal, 1997). To meet this demand for flexibility, organisations are increasingly counting on human flexibility to create a competitive advantage in the globalised economy (Peiro, Garcia-Montalvo, \& Gracia, 2002; Reilly, 1998a). To achieve such flexibility, organisations might not only count on the flexibility of their employees, but might in their recruitment process also select unemployed individuals who are willing to be flexible.

Some studies on individuals' attitudes towards labour market flexibility have found inter-individual differences in the willingness to accept jobs that require some form of flexibility (e.g. Peiro et al., 2002; van den Berg \& van der Velde, 2005). Most of these studies describe which background characteristics such as age, marital status, and educational level are associated with the willingness to adopt a flexible attitude, but lack a strong theoretical framework. In addition, these studies focus on specific groups such as youngsters (e.g. Peiro et al., 2002) or employees from a specific firm (e.g. Van den Berg \& van der Velde, 2005). Therefore the generalisability of their results to more heterogeneous samples and unemployed individuals remains to be demonstrated.

This study aimed to examine unemployed individuals' attitudes towards flexibility in greater detail. Specifically, as values are considered to be important antecedents of individuals' attitudes (De Witte, 2004; Rokeach, 1973), we rely on the concepts of work values to predict variability in unemployed individuals' attitudes towards job flexibility. The concept of values is approached from two theoretical angles, that is, Expectancy-Value Theory (EVT; Feather, 1982, 1989) and Self-Determination Theory (SDT; Deci \& Ryan, 2000; Vansteenkiste, Lens, \& Deci, 2006). EVT deals with the motivational consequences of the importance people ascribe to being employed in

(C) 2009 The Authors. Journal compilation (C) 2009 International Association of Applied Psychology. 
general (e.g. employment value). The validity of employment value for the context of unemployment has been documented extensively (e.g. Feather \& O'Brien, 1986). Its predictive validity regarding unemployed individuals' flexibility, however, remains to be demonstrated. SDT has only recently been applied to the context of unemployment (e.g. Vansteenkiste, Lens, Dewitte, De Witte, \& Deci, 2004). This theory may, however, help to understand how different types of unemployed individuals' work values (i.e. intrinsic vs. extrinsic; Kasser \& Ryan, 1996) are related to the acceptance of jobs requiring different types of flexibility. Before detailing EVT and SDT and presenting our hypotheses regarding the relations between values and unemployed individuals' flexibility, we introduce the concept of flexibility among unemployed individuals and specify some of its different types.

\section{FLEXIBILITY AMONG UNEMPLOYED INDIVIDUALS}

Flexibility has become a central component of various organisational design and management theories (Tregaskis, Brewster, Mayne, \& Hegewisch, 1998) and has been studied in different aspects including organisational flexibility, technological flexibility, and workforce flexibility (Kara, Kayis, \& O'Kane, 2002). Consequently, a broad range of definitions and typologies on flexibility has been developed (Reilly, 1998a, 1998b). In spite of or perhaps due to these different approaches, the concept of flexibility itself remains rather unclear. Most definitions of flexibility, however, have in common that they refer to "an ability to respond effectively to changes".

This study deals with the flexibility of unemployed individuals and their attitudes towards the changing demands and job offers of the labour market. Therefore, we define unemployed individuals' flexibility as the strictness of their demands regarding their future job, that is, their willingness to accept a job that deviates from a standard job (De Witte, 1993; Vandoorne, De Witte, $\&$ Hooge, 2000). If unemployed individuals are willing to accept any job that is offered to them, even those that require additional effort or sacrifices, they are said to be highly flexible. In contrast, if unemployed individuals are narrowly focused on particular types of jobs, they are said to demonstrate a low level of flexibility. Unemployed people's flexibility is likely to covary with the length of their unemployment and/or the number of rejected job offers (De Witte, 1993; Kanfer, Wanberg, \& Kantrowitz, 2001). Obviously, as highly flexible unemployed individuals are less picky, they can choose from a wider set of job offers and will probably more easily and swiftly find a job compared to less flexible unemployed individuals.

The current study focuses on four types of flexibility, which are related to the dimensions of underemployment as defined by Feldman (1996); that is, training flexibility, pay flexibility, flexibility to accept an undemanding job, and flexibility to accept a job for which one is over-qualified. First, training

(C) 2009 The Authors. Journal compilation (C) 2009 International Association of Applied Psychology. 
flexibility refers to the willingness of unemployed individuals to attend an additional training programme to gain (re)employment. Unemployed individuals' training flexibility is related to Feldman's concept of underemployment in terms of having a job outside the area of one's formal education (Feldman, 1996). It is equivalent to employees' training motivation, which concerns employees' willingness to broaden their skills and competencies through training courses (Kanfer et al., 2001). Second, pay flexibility concerns the rigour of unemployed individuals' referential or minimum wage that must be offered before they consider a job to be financially worthwhile (Jones, 1988). It refers to the willingness to accept a job that pays less compared to their former job or compared to what can be expected based on their educational level. Unemployed individuals' pay flexibility is related to Feldman's concept of underpayment. Third, underemployment flexibility refers to an unemployed person's willingness to accept a job that requires lower qualifications than (s)he possesses in terms of education or work experience (Feldman, 1996). Finally, the flexibility to accept an undemanding job can be described as an unemployed person's willingness to accept an uninteresting and less challenging job.

Although various other types of flexibility exist (e.g. temporal flexibility, locational flexibility; Reilly, 1998a), studying the antecedents of the aforementioned types of flexibility is particularly important as they are likely to lead to employment of a different quality and, hence, might yield different effects on individuals' well-being and behaviour over time (Feldman, 1996). If unemployed individuals are, for instance, flexible in accepting underemployment, they are likely to arrive at a situation of over-qualification, which has been found to be associated with lower job satisfaction and organisational commitment and higher turnover intentions (e.g. Maynard, Joseph, \& Maynard, 2006). Equally, theories and empirical studies on job characteristics (e.g. Hackman \& Oldham, 1976; Warr, 1987) and job-person fit (e.g. Kristof-Brown, Zimmerman, \& Johnson, 2005) suggest that a lack of skill utilisation, which is likely to follow from accepting an undemanding job, might yield negative consequences. In contrast, if unemployed individuals are flexible in accepting a job that requires an additional training programme, they are likely to benefit from doing so. Previous research has shown that employees' willingness to attend a training programme is associated with increased skill acquisition, self-efficacy, organisational commitment, job involvement, and career exploration (e.g. Colquitt, Lepine, \& Noe, 2000).

To our knowledge, only one study has examined the relationships between individuals' values and their attitudes towards flexibility (Peiro et al., 2002). These authors showed that youngsters who strongly value extensive holidays, little pressure, and job security were more willing to accept underemployment or a job that does not offer the opportunity to use their skills. In

(C) 2009 The Authors. Journal compilation (C) 2009 International Association of Applied Psychology. 
contrast, youngsters who value having responsibility and opportunities to learn were unwilling to accept a job that lacked learning opportunities, but were flexible in accepting a job that would require higher qualifications. The present study aims to extend this work by (a) sampling a group of unemployed individuals, (b) including assessments of pay flexibility and training flexibility in addition to the flexibility to accept underemployment and an undemanding job, and (c) using two well-established social motivational frameworks (i.e. EVT and SDT), which are presented in more detail in the following section.

\section{UNEMPLOYED INDIVIDUALS' VALUES AND FLEXIBILITY}

To define individuals' work values more precisely and to derive hypotheses concerning the relationships between work values and flexibility, we rely on Expectancy-Value Theory (EVT; Vroom, 1964; Feather, 1990) and SelfDetermination Theory (SDT; Deci \& Ryan, 2000).

\section{Expectancy-Value Theory}

Expectancy-Value Theory (Vroom, 1964) is a cognitive-motivational model in which individuals' motivation to strive for or choose a particular goal is regarded as a (multiplicative) function of their expectancies to successfully attain this goal and the subjective valence the individual ascribes to that goal. According to Feather (1990, 1992a, 1992b), who applied EVT to the context of unemployment, valences may originate from more general values, as values would function as standards or criteria that determine people's attitudes and behaviours.

Apart from paying some attention to individuals' valuation of specific job aspects such as opportunities for skill utilisation, variety, and influence (e.g. Feather \& O'Brien, 1986), most attention within EVT has been paid to the general concept of employment value or employment commitment. The concept of employment value describes a general attachment to work or the general importance ascribed to having a job or being employed (see also Isaksson, Johansson, Bellaagh, \& Sjoberg, 2004; Jackson, Stafford, Banks, \& Warr, 1983). Employment value is a central aspect of the experience of work because it determines the meaning that work, jobs, and related experiences have for people (George \& Jones, 1997).

According to EVT, unemployed individuals who highly value employment are willing to engage in various behaviours to achieve employment and invest a considerable amount of psychological and physical energy in finding a job (Kanfer et al., 2001). Because being flexible might help unemployed individuals to realise their highly valued goal of finding (re)employment, unemployed

(C) 2009 The Authors. Journal compilation (C) 2009 International Association of Applied Psychology. 
individuals who strongly value being employed might be more in favour of being flexible and accept any type of job. In line with this reasoning, we hypothesised that:

Hypothesis 1: Employment value positively predicts all the aforementioned types of flexibility; that is: training flexibility, pay flexibility, flexibility to accept undemanding work, and flexibility to accept underemployment.

In examining the extent to which work and employment occupy a central place in unemployed persons' lives, EVT researchers have mainly been paying attention to the level or quantity of unemployed individuals' motivation to find a job (Vansteenkiste, Lens, De Witte, \& Feather, 2005). However, in addition to how much importance an unemployed person ascribes to employment, the content or quality of people's work values could also be considered (Kanfer et al., 2001). Not all unemployed individuals who highly value employment will be focused on the same type of work values. The different types of work values which unemployed individuals hold might predict their degree and type of job flexibility. Self-Determination Theory (SDT; Deci \& Ryan, 2000; Vansteenkiste, Ryan, \& Deci, in press) might help to shed light on this issue.

\section{Self-Determination Theory}

In SDT, intrinsic values such as personal growth, emotional intimacy, community contribution, and health are differentiated from extrinsic values such as financial success, appealing appearance, status, and power (Kasser, 2002; Vansteenkiste, Soenens, \& Duriez, 2008). These different value orientations are suggested as being associated with different outcomes. As intrinsically oriented individuals are focused on developing and actualising their inherent potential, they are likely to satisfy their basic psychological needs for autonomy, competence, and relatedness and therefore function optimally (Kasser \& Ryan, 1996). Extrinsically oriented individuals, in contrast, adopt an outward oriented focus and try to impress others by acquiring external signs of worth or importance. This impression management might lead them to engage in various stressful interpersonal comparisons (Lyubomirsky \& Ross, 1997) and to develop a contingent sense of self-worth (Kernis, Brown, \& Brody, 2000), which are likely to forestall their well-being and performance (Sheldon, Ryan, Deci, \& Kasser, 2004). An excessive focus on extrinsic values might also come at the expense of the pursuit of intrinsic values and is therefore unrelated or even antagonistic to basic psychological need satisfaction, which might further undermine individuals' adjustment and optimal performance (Vansteenkiste, Neyrinck, Niemiec, Soenens, De Witte, \& Van den Broeck, 2007).

(C) 2009 The Authors. Journal compilation (C) 2009 International Association of Applied Psychology. 
In most SDT research (e.g. Kasser \& Ryan, 1996), a relative measurement is used to study the effects of intrinsic, relative to extrinsic, value orientations on well-being, attitudes, and performance. These studies have shown that pursuing intrinsic, compared to extrinsic, life value orientations positively predicts well-being and optimal functioning (for overviews, see Kasser, 2002). Recently, Vansteenkiste et al. (2007) found that holding an extrinsic, relative to an intrinsic, work value orientation as an employee was associated with lower job satisfaction, job vitality, and job commitment and higher exhaustion (see also Amabile, Hill, Hennessey, \& Tighe, 1994; Knoop, 1994). These direct relationships were mediated by employees' basic need satisfaction. The current study aims to build on this work by applying the distinction between intrinsic and extrinsic work values in a new domain (i.e. unemployment) and by examining the predictive validity of these different types of work values for new outcomes (i.e. types of flexibility).

Based on SDT, it is expected that the type of flexibility unemployed individuals are willing to display varies as a function of the content of their work values. Specifically, it is argued that, all other things being equal, unemployed individuals will be flexible in accepting particular types of jobs only if these jobs allow them to realise their work values. Because intrinsically oriented unemployed individuals highly value personal development and growth at work, they were expected to be more likely to accept a job that requires them to follow additional training. This is because following such a training programme would be perceived as contributing to their personal growth. Furthermore, intrinsically oriented individuals would be unwilling to accept an undemanding job or underemployment, because such jobs provide only limited opportunities for skill development. Individuals who hold an extrinsic work value orientation would be less flexible in accepting an underpaid job because such jobs do not allow them to realise their extrinsic work value orientation. As underemployment is unlikely to be paid well and provides little status, it is also less attractive for extrinsically oriented individuals. In sum, based on SDT, we hypothesised that:

Hypothesis 2: An intrinsic work value orientation is positively related to training flexibility and negatively to flexibility to accept an undemanding job and the flexibility to accept underemployment.

Hypothesis 3: Holding an extrinsic work value orientation is negatively related to pay flexibility and the flexibility to accept underemployment.

These hypotheses were examined in a heterogeneous group of unemployed individuals after controlling for various background variables, including unemployed individuals' gender, age, education, professional level, unemployment duration, and perceived financial hardship.

(C) 2009 The Authors. Journal compilation (C) 2009 International Association of Applied Psychology. 


\section{METHOD}

\section{Participants and Procedure}

The data were collected in 2001 in Flanders, the Dutch speaking part of Belgium. At that time 6.4 per cent of the potential workforce was unemployed (www.steunpuntwav.be). Participants were recruited via individual or collective information sessions held by a Belgian government organisation (the $\mathrm{VDAB}^{1}$ ) which aims to support unemployed individuals to find employment. In Belgium, unemployed individuals regularly attend such sessions to increase their job application skills and their chances of finding (re)employment. Whereas some sessions were mandatory (e.g. individual counselling to screen the labour market skills and perspectives of the unemployed), others were optional (e.g. job applicant information sessions). During these sessions, participants were asked to fill out the questionnaire or were invited to take a questionnaire home and to return it to the office of the government programme, from which it was collected by the researchers. The cover letter of the questionnaire emphasised the research purpose of the study and stressed anonymity and confidentiality of the answers. The questionnaires were offered to 350 unemployed individuals; 284 returned the questionnaires and constituted the final sample (response rate $=81 \%$ ).

Thirty-seven per cent of the participants $(N=106)$ were male and 58 per cent $(N=165)$ were female; 5 per cent $(N=13)$ failed to disclose their gender. Thirty-seven per cent of the participants $(N=104)$ were younger than 25 years; 40 per cent $(N=113)$ were aged between 26 and 40 years and 18 per cent $(N=52)$ were older than 41 years. Five per cent of the participants $(N=15)$ did not fill out their age. Concerning participants' level of education, 8 per cent $(N=24)$ were very poorly educated (i.e. primary education), 22 per cent $(N=63)$ finished grade 9,43 per cent $(N=123)$ were moderately educated (i.e. high school), 17 per cent $(N=47)$ had a college or university degree, and 10 per cent $(N=27)$ did not provide information about their level of education. Considering professional level, 34 per cent $(N=97)$ of the participants were previously employed as a blue-collar worker, 28 per cent $(N=80)$ had been employed as a white-collar worker, 11 per cent $(N=32)$ had been a member of an organisation's board, 5 per cent $(N=15)$ had been self-employed, 12 per cent $(N=34)$ had never been employed, and 9 per cent $(N=26)$ did not disclose their former professional level. Concerning length of unemployment, participants indicated one of eight categories (i.e. less than 3 months, between 3 and 6 months, between 6 and 9 months, between 9 and 12

\footnotetext{
${ }^{1}$ The VDAB is the "Vlaamse Dienst voor Arbeidsbemiddeling en Beroepsopleiding" or the Flemish Governmental Employment Office for Employment-Finding and Occupational Training.
}

(C) 2009 The Authors. Journal compilation (C) 2009 International Association of Applied Psychology. 
TABLE 1

Comparison between the Sample and the General Population

\begin{tabular}{lcc}
\hline & Sample $(\%)$ & Population (\%) \\
\hline Gender & & \\
$\quad$ Male & 39.1 & 44.1 \\
$\quad$ Female & 60.9 & 55.9 \\
Age & & \\
$\quad<25$ years & 38.7 & 25.6 \\
$26-40$ years & 42.0 & 40.7 \\
$\quad 41$ and older & 19.3 & 33.7 \\
Education & & 58.5 \\
$\quad$ Poor education & 33.8 & 31.0 \\
$\quad$ Midlevel & 47.9 & 10.5 \\
$\quad$ High level & 18.3 & 57.6 \\
Unemployment duration & & 42.4 \\
$\quad$ Less than 1 year unemployed & 69.4 & 100 \\
$\quad$ year or more & 30.6 & \\
Total & 100 & \\
\hline
\end{tabular}

Source: http://arvastat.vdab.be/nwwz/index.htm.

Column percentages for the sample are recalculated without the missing values.

months, between 1 year and 2 years, between 2 and 5 years, between 5 and 10 years, more than 10 years). Overall, 20 per cent of the participants $(N=58)$ were less than 3 months unemployed, another 20 per cent $(N=57)$ were unemployed between 3 and 6 months, 26 per cent $(N=73)$ were unemployed between 6 months and 1 year, 29 per cent $(N=83)$ were unemployed for more than 1 year, and 5 per cent of the participants $(N=13)$ did not provide information regarding their length of unemployment. Concerning their job search behaviour, 23 per cent of the participants $(N=65)$ noted that they were not really looking for a job, 36 per cent $(N=102)$ declared that they were searching passively; that is, they considered the vacancies offered to them, but did not actively search for job openings, 41 per cent $(N=117)$ stated that they were actively searching for a job and were taking the initiative to find (re)employment.

As shown in Table 1, the sample is not representative of the population of unemployed individuals in Flanders at the time of the survey (http:// arvastat.vdab.be/nwwz/index.htm). The slight underrepresentation of older and long-term unemployed individuals is probably due to the fact that some of the sessions targeted especially younger unemployed of shorter duration (e.g. individual counselling). The underrepresentation of the poorly educated unemployed is probably due to the fact that poorly educated individuals tend to participate less in surveys with written questionnaires (Rogelberg, 2002). Women are slightly overrepresented in the sample.

(C) 2009 The Authors. Journal compilation (C) 2009 International Association of Applied Psychology. 


\section{Measures}

Perceived Financial Hardship. Financial hardship was measured with a single item, "How much difficulty do you experience in making ends meet with your total net income?" It was scored on a 5-point Likert scale, ranging from 1 (No Difficulty at All) to 5 (Much Difficulty; $M=3.12 ; S D=1.06$ ).

Values. General employment value was measured with a widely used questionnaire, which can be found in the Appendix (e.g. Feather, 1990). Participants indicated on a 5-point Likert scale from 1 (Completely Disagree) to 5 (Completely Agree) to what extent they valued having a job and disliked being unemployed. Cronbach's $\alpha$ of this 14 -item scale was $.84(M=2.98$; $S D=.71)$. Intrinsic Work Values were measured with five items such as "I find it important to have an interesting job". The scale for Extrinsic Work Values contained three items such as "I find it important to find a job that provides a high social status". Items were rated on a 5-point Likert scale ranging from 1 (Not Important at All) to 5 (Very Important). Internal consistency of the intrinsic $(M=4.28 ; S D=.61)$ and extrinsic $(M=3.66$; $S D=.81$ ) work value orientation scales was .82 and .71 , respectively.

To examine whether these three sets of value items load on different factors, we performed a Confirmatory Factor Analysis (CFA), using LISREL 8.50 with maximum likelihood estimation on all value items (Jöreskog \& Sörbom, 2004). As data non-normality at the univariate and the multivariate levels was detected, the asymptotic covariance matrix was used in addition to the covariance matrix, and the Satorra-Bentler Scaled chisquare (SBS- $\chi^{2}$; Satorra \& Bentler, 1994) was inspected. To evaluate the goodness of fit of the imposed factor structure, we examined the Root Mean Square Error of Approximation (RSMEA), the Standardised Root Mean Square Residual (SRMR), and the Comparative Fit Index (CFI). According to Kline (2005) cut-off values of .08 for RSMEA and SRMR and .90 for CFI indicate adequate fit. Two items of general employment value were removed due to low factor loadings ( $\gamma=.12$ and .06 , respectively). The final model distinguished between the three factors for employment value, intrinsic work values, and extrinsic work values and included four error correlations among six items of the general employment value measurement. The model yielded an adequate fit to the data; SBS- $\chi^{2}(163)=321.70, p<.001$; RSMEA $=.06$, $\mathrm{SRMR}=.07$, and CFI $=.88$. All observed variables had significant $(p<.001)$ and moderate to strong loadings (ranging from .49 to .87) on their latent factor. Most importantly, the model containing three factors fit the data better than the one-factor model $\left(\Delta \chi^{2}(3)=395.60\right)$ or the two-factor models in which employment value $\left(\Delta \chi^{2}(2)=122.99\right)$, intrinsic values $\left(\Delta \chi^{2}(2)=117.07\right)$, or extrinsic values $\left(\Delta \chi^{2}(2)=288.91\right)$ are opposed to the other value items; all $p$ s $<.001$.

(C) 2009 The Authors. Journal compilation (C) 2009 International Association of Applied Psychology. 
Flexibility. The flexibility scale assessed participants' attitudes towards future jobs that required particular types of flexibility. The 11 questions were taken from a questionnaire constructed by De Witte (2001). Participants indicated on a scale from 1 (Totally Disagree) to 5 (Totally Agree) to what extent they were willing to accept a job that would require (a) training flexibility (e.g. "I am willing to accept a job that requires me to follow additional training for 6 months"; three items; $M=3.74, S D=.91 ; \alpha=.66$ ); (b) pay flexibility (e.g. "I am willing to accept a job that pays less well than usual, given my level of schooling"; two items; $M=2.50, S D=1.11 ; \alpha=.82$ ); (c) flexibility to accept an undemanding job (e.g. "I am willing to accept a boring and undemanding job"; four items; $M=1.94, S D=.77 ; \alpha=.73$ ); (d) flexibility to accept underemployment (e.g. "I am willing to accept a job below my level of education"; two items; $M=2.63, S D=1.05 \alpha=.74$ ). CFA using LISREL 8.50 showed that the four-factor model yielded a good fit to the data; SBS- $\chi^{2}(38)=66.24, p<.001 ;$ RSMEA $=.06$, SRMR $=.09$, and CFI $=.95$. Factor loadings ranged from .40 to .89 , all $p s<.001$. The four-factor model fit the data better than any other three-, two-, or one-factor model, which further supports the distinctiveness of the different types of flexibility.

\section{RESULTS}

\section{Preliminary Analyses}

Independent $t$-testing indicated that male participants $(M=2.05)$ were more likely to accept an undemanding job than female $(M=1.86)$ participants, $t(264)=1.95, p=.05$. No other significant gender effects were found. Pearson's correlation coefficients between the measured variables can be found in Table 2. Age was negatively correlated with level of education, professional level, and an intrinsic work value orientation, and was positively correlated with unemployment length. Educational level was positively correlated with professional level, an intrinsic work value orientation, and training flexibility, whereas it was negatively correlated with length of unemployment, an extrinsic work value orientation and the flexibility to accept an undemanding job. Unemployment length correlated positively with perceived financial hardship and negatively with employment value and training flexibility. Perceived financial hardship also related positively to employment value and an extrinsic work value orientation.

Concerning the intercorrelations between the psychological variables, employment value was positively related to an extrinsic work value orientation and to all four types of job flexibility. An intrinsic work value orientation was positively correlated with an extrinsic work value orientation and training flexibility and was negatively correlated with the willingness to accept an undemanding job. Holding an extrinsic work value orientation was

(C) 2009 The Authors. Journal compilation (C) 2009 International Association of Applied Psychology. 


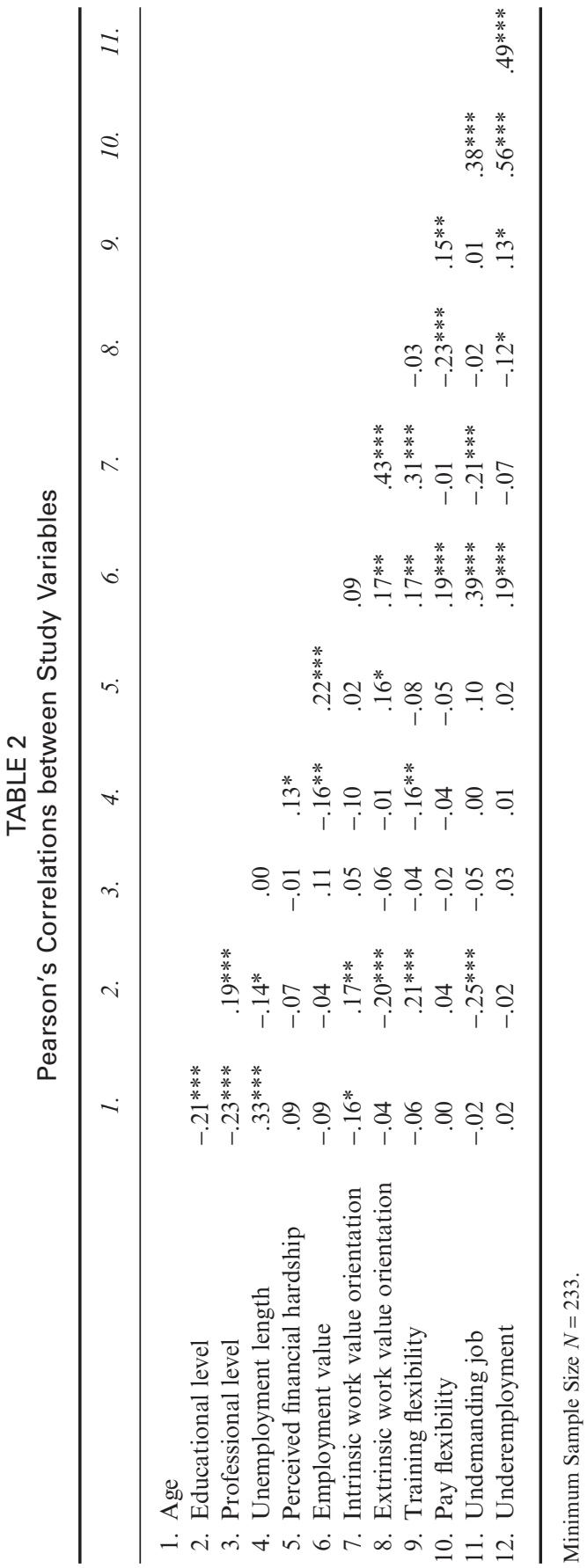

(C) 2009 The Authors. Journal compilation (C) 2009 International Association of Applied Psychology. 
negatively correlated with pay flexibility and the willingness to accept underemployment. Training flexibility was positively related to pay flexibility and the flexibility to accept underemployment. Pay flexibility, flexibility to accept an undemanding job, and the flexibility to accept underemployment were positively correlated. Overall, the correlational findings indicated that, as expected, employment value was positively correlated with all types of job flexibility and the findings tended to support our hypotheses regarding the differential associations between intrinsic and extrinsic work value orientations and job flexibility.

\section{Primary Analyses}

As we deemed it important to examine whether the observed relations at the correlational level would hold after controlling for background variables, and because we aimed to examine the unique predictive validity of the three values measures, we proceeded by conducting a set of hierarchical regression analyses. Herein, the control variables (i.e. gender, age, educational level, financial hardship, and employment length) were entered in Step 1, whereas employment value was added in Step 2, and intrinsic and extrinsic work value orientations were added simultaneously in Step 3. The results can be found in Table 3.

As can be noticed in Step 1, level of education and unemployment length were respectively positively and negatively related to training flexibility. Gender and level of education negatively predicted individuals' willingness to accept an undemanding job. Age, professional level, and perceived financial hardship did not yield unique associations with any of the types of job flexibility.

When entered in Step 2, employment value was found to be positively associated with all types of job flexibility. The amount of explained outcome variance by employment value above and beyond these demographic variables varied between 3 per cent and 14 per cent. The insertion of intrinsic and extrinsic work value orientations in Step 3 resulted in a further significant increase in explained variance in training flexibility (14\%) and pay flexibility $(8 \%)$. More specifically, an intrinsic work value orientation was positively related to training and pay flexibility, whereas an extrinsic work value orientation was negatively related to both these types of flexibility. Employment value remained a significant positive predictor of all types of job flexibility after introducing intrinsic and extrinsic work value orientations in Step 3.

\section{DISCUSSION}

This study aimed to advance our understanding of unemployed individuals' attitudes towards flexibility by studying their willingness to be flexible in

(C) 2009 The Authors. Journal compilation (C) 2009 International Association of Applied Psychology. 


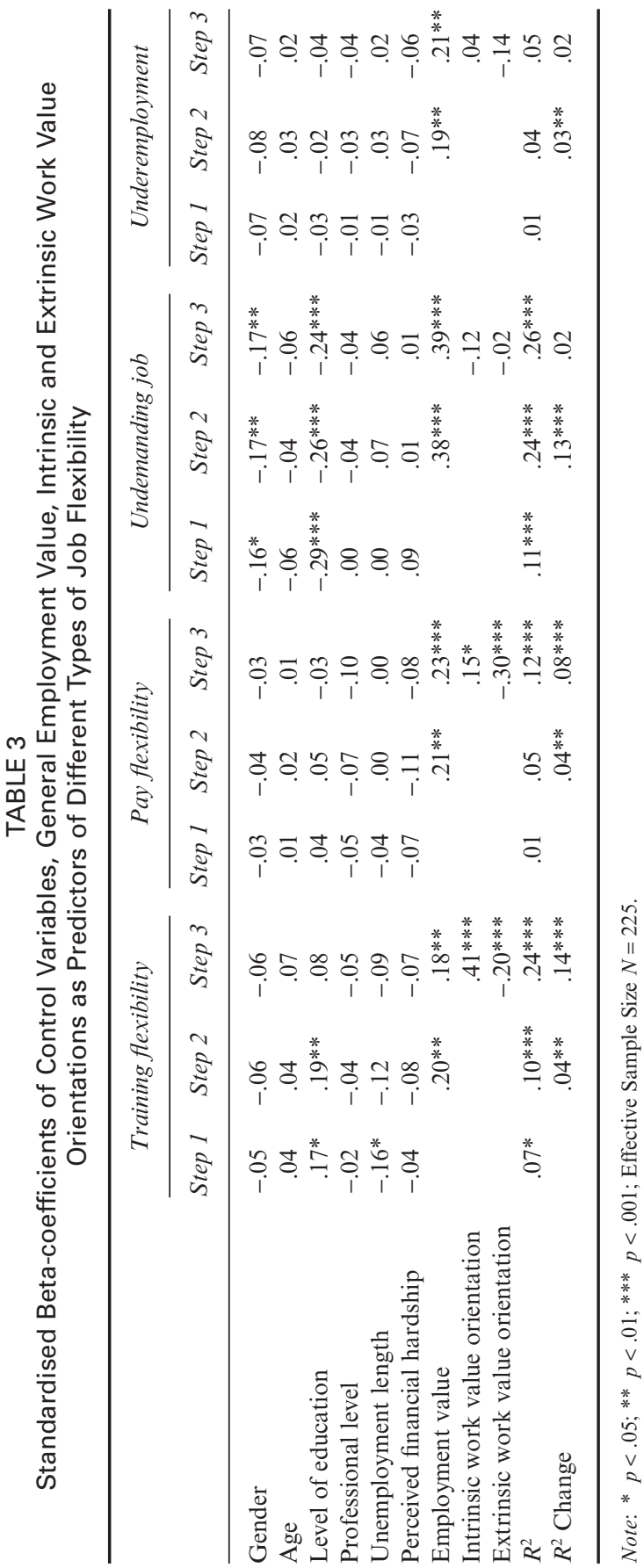


accepting jobs which require additional training or jobs which are poorly paid, undemanding, or for which they were over-qualified. As values are considered important determinants of individuals' attitudes (Rokeach, 1973), we aimed to examine the relationships between unemployed individuals' values and their willingness (i.e. positive attitude) versus resistance (i.e. negative attitude) to be flexible. In doing so, we made use of two wellvalidated motivational frameworks; that is, Expectancy-Value Theory (EVT) and Self-Determination Theory (SDT) which have both been applied to the context of unemployment. Based on EVT, we predicted that attaching great importance to being employed would be associated with accepting all types of flexibility that were examined. Based on SDT, we expected that by making a qualitative differentiation between intrinsic and extrinsic value orientations, a more selective pattern of acceptance of particular types of flexibility would emerge.

In line with our first hypothesis, results showed that general employment value was positively related to all the studied types of flexibility. The more unemployed individuals value being employed, the less they have particular wishes concerning their future job, and the more they are willing to accept any job that is offered to them. These results are consistent with EVT, which suggests that unemployed people who are highly committed to employment might go to great lengths to get a job. Notably, employment value showed a particularly strong relationship with the flexibility to accept an undemanding job. Unemployed individuals who strongly value being employed are perhaps most flexible in accepting this type of job, because it represents the most likely way of becoming employed, as few people desire such jobs. Indeed, the mean score for this type of flexibility is very low $(M=1.94)$ and lower than the mean scores of the three other types of flexibility. Thus, opting for an undemanding job might be the shortest route to becoming employed, the ultimate goal of unemployed individuals who highly value employment.

The predictions derived from SDT were not fully supported. As expected, unemployed individuals who hold an intrinsic work value orientation were more willing to accept a job that requires them to follow additional training. Although not expected, they were also more flexible in accepting a job that is relatively lowly paid. Presumably, when unemployed individuals perceive a job as a means to develop their talents, they are more willing to follow job training that is likely to help them in attaining these values and they care less about the salary of their future job. Intrinsic work value orientations correlated negatively with the flexibility to accept an undemanding job. However, this relationship disappeared after controlling for the participants' level of education. This suggests that the association between an intrinsic work value orientation and the flexibility to accept an undemanding job is due to their relationship with level of education. The finding that highly educated individuals are less flexible in accepting an undemanding job is consistent with

(C) 2009 The Authors. Journal compilation (C) 2009 International Association of Applied Psychology. 
previous research (e.g. De Witte, 1993), and might be due to the better position of highly compared to poorly educated individuals on the labour market, which gives higher educated unemployed individuals the opportunity to refuse jobs of low quality. Instead of the predicted negative association, a zero-order relationship was found between intrinsic work value orientations and the flexibility to accept underemployment. Contrary to expectations, holding an intrinsic work value orientation does not restrain unemployed individuals from accepting jobs which require a lower level of education or experience than they possess. This could, however, be a rational choice, as such jobs could be offering more opportunities for self-development and, hence, fulfilment of their values, than their situation of unemployment (e.g. Feldman, 1996). Future research could examine this possibility more closely.

In line with SDT, an extrinsic work value orientation predicted less flexibility in accepting an underpaid job. The predicted negative effect on accepting underemployment was not found. Furthermore, an extrinsic work value orientation yielded a significant negative relationship with training flexibility. In general, compared to an intrinsic work value orientation, the focus on extrinsic work values thus seems to limit unemployed individuals' willingness to adopt a flexible attitude towards the labour market. In sum, the results of this study show that whereas employment value positively predicts the willingness to accept any of the four types of job flexibility, holding an intrinsic versus extrinsic work value orientation seems differentially related to the diverse types of unemployed people's job flexibility.

A question that needs to be addressed in future research is whether all types of job flexibility are likely to yield benefits for the flexible unemployed person. Although longitudinal research is needed to examine this question, it can be derived from various work and organisation theories, including models on job-person fit (Kristof-Brown et al., 2005) and job characteristics (Warr, 1987) that, for instance, the willingness to accept an undemanding job is unlikely to contribute to skill utilisation and the satisfaction of the basic psychological needs for autonomy, competence, and relatedness (Ryan, 1995). Accepting an undemanding job is thus likely to result in underemployment which yields an increased risk for distress, low job satisfaction, and low organisational commitment (De Witte, 1993; Feldman, Leana, \& Bolino, 2002; Johnson, Morrow, \& Johnson, 2002). Similarly, if unemployed people give higher priority to the remuneration rate of their future job compared with its content, they might end up choosing a well-paid but poor-quality job. Training flexibility might, in contrast, represent a better alternative to attaining high quality jobs and therefore contribute to an unemployed individual's well-being. Thus, in line with research on underemployment, we argue for a critical view towards the concept of job flexibility. Notably, it is not only to the advantage of unemployed people, but also to the advantage of employers (Leana \& Feldman, 1995) and society at large (Dooley \& Prause, 2004) that

(C) 2009 The Authors. Journal compilation (C) 2009 International Association of Applied Psychology. 
unemployed people choose the "right" job instead of accepting any kind of job that is offered to them.

From a practical point of view, these results suggest that job consultants may want to reduce unemployed individuals' extrinsic work value orientations, and to stimulate intrinsic work value orientations and general employment value to increase unemployed individuals' flexibility. However, as noted above, although being highly flexible as an unemployed person might provide short-term benefits (i.e. employment), it might yield some risks in the long term as it might lead to the selection of non-satisfying jobs. In particular, unemployed individuals who are heavily focused on becoming employed seem to be vulnerable to accepting a job that could result in underemployment. Given these considerations, the present research suggests that job consultants might predominantly try to stimulate intrinsic value orientations, as intrinsic work value orientations are likely to covary with qualitatively good types of flexibility. Job consultants may enhance unemployed individuals' intrinsic work value orientations by framing the search for employment as an opportunity to realise intrinsic values and stressing the importance of self-development and skill utilisation in future jobs. Previous research has shown that individuals' intrinsic versus extrinsic goal orientation can be enhanced if a particular activity is framed in terms of intrinsic instead of extrinsic values (Vansteenkiste, Simons, Lens, Sheldon, \& Deci, 2004).

\section{Limitations and Future Directions}

This study is not without limitations. First, although heterogeneous instead of organisation- or age-specific in nature (e.g. Peiro et al., 2002), the present sample was not representative, which limits the generalisability of the current results. However, in our view, there is no reason to expect that the observed structural relationships between values and flexibility will strongly vary across different subgroups of unemployed individuals, as the relationships between psychological measures as used in the current research tend to be relatively stable. Second, as data were gathered through self-reports, common method variance might artificially inflate the strength of the observed relationships. However, self-ratings seem to be the most feasible way to asses individuals' values and attitudes, as these concepts represent subjective experiences which need to be rated by individuals themselves. Third, because of the study's cross-sectional design, conclusions regarding causality are limited. Longitudinal research might help to examine the causal relationships between unemployed people's or school-leavers' work values, their job flexibility, and the type of jobs that they are effectively choosing. Furthermore, we suggest that the measurement of intrinsic and extrinsic work value orientations should be improved and extended, as SDT (Kasser \& Ryan, 1996) distinguishes various types of extrinsic work values (e.g. social

(C) 2009 The Authors. Journal compilation (C) 2009 International Association of Applied Psychology. 
recognition, power, financial success) and various types of intrinsic work values (e.g. personal growth, affiliation, and community contribution). Future research could also expand the range of job flexibility types by including the willingness to accept temporary or part-time work, to work shifts or to accept a job in which one must alternate between various different functions. Finally, we encourage further research to include other value types (e.g. Schwartz, 1992) and more specific values (e.g. Feather \& O'Brien, 1986) and examine other potential determinants of unemployed people's flexibility such as openness to experience, the number of rejections during job applications, and labour market possibilities (Kanfer et al., 2001).

\section{Conclusion}

The present research indicates that the concept of work or employment value is useful in predicting the degree to which unemployed individuals are willing to respond to the labour market's demand for flexibility. Employment value, as an indicator of the strength of unemployed people's motivation to find (re)employment, was found to indifferently predict job flexibility. In contrast, when differentiating between qualitatively different types of work value orientation, it was found that holding an intrinsic work value orientation related positively to training and pay flexibility, whereas holding an extrinsic work value orientation related negatively to these two types of flexibility. These findings extend previous unemployment research within EVT which showed that employment value predicts higher job search behaviour and lower mental health (e.g. Feather \& O'Brien, 1986; O'Brien \& Feather, 1990) and suggests that SDT is not only a useful motivational theory to understand unemployed individuals' well-being and behaviour (e.g. Vansteenkiste, Lens et al., 2005), but also to predict their attitudes towards the labour market.

\section{REFERENCES}

Aggarwal, S. (1997). Re-engineering: A breakthrough or little new. International Journal of Technology Management, 13, 326-344.

Amabile, T., Hill, K., Hennessey, B., \& Tighe, E. (1994). The work preference inventory: Assessing intrinsic and extrinsic motivational orientations. Journal of Personality and Social Psychology, 66, 950-967.

Brewster, C., Mayne, L., \& Tregaskis, O. (1997). Flexible working in Europe. Journal of World Business, 32, 133-151.

Colquitt, J., LePine, J., \& Noe, R. (2000). Toward an integrative theory of training motivation: A meta-analytic path analysis of 20 years of research. Journal of Applied Psychology, 85, 678-707.

Deci, E., \& Ryan, R. (2000). The "what" and "why" of goal pursuits: Human needs and the self-determination of behavior. Psychological Inquiry, 11, 227-268.

(C) 2009 The Authors. Journal compilation (C) 2009 International Association of Applied Psychology. 
De Witte, H. (1993). Gevolgen van langdurige werkloosheid voor het psychisch welzijn: overzicht van de onderzoeksliteratuur [Consequences for psychological well-being of long-term unemployment: Review of the literature]. Psychologica Belgica, 33, 1-35.

De Witte, H. (2001). Studenten over flexibiliteit en tijdelijk werk [Students' evaluations of flexibility and temporary jobs]. Over. Werk: Tijdschrift van het Steunpunt WAV, 11(1-2), 202-206.

De Witte, H. (2004). Ideological orientation and values. In C. Spielberger (Gen. Ed.), Encyclopedia of applied psychology (Vol. 2; pp. 249-258). New York: Elsevier.

Dooley, D., \& Prause, J. (2004). The social costs of underemployment: Inadequate employment as disguised unemployment. New York: Cambridge University Press.

Feather, N.T. (1982). Unemployment and its psychological correlates: A study of depressive symptoms, self esteem, protestant ethic values, attributional style and apathy. Australian Journal of Psychology, 34, 309-323.

Feather, N.T. (1989). The effects of unemployment on work values and motivation. In U. Kleinbeck, H. Quast, H. Thierry, \& H. Hacker (Eds.), Work motivation (pp. 201-230). Hillsdale, NJ: Erlbaum.

Feather, N.T. (1990). The psychological impact of unemployment. New York: Springer.

Feather, N.T. (1992a). Expectancy-value theory and unemployment effects. Journal of Occupational and Organizational Psychology, 65, 315-330.

Feather, N.T. (1992b). Values, valences, expectations, and actions. Journal of Social Issues, 48, 109-124.

Feather, N.T., \& O'Brien, G. (1986). A longitudinal analysis of the effects of different patterns of employment and unemployment on school-leavers. British Journal of Psychology, 77, 459-479.

Feldman, D. (1996). The nature, antecedents and consequences of underemployment. Journal of Management, 22, 385-407.

Feldman, D., Leana, C., \& Bolino, M. (2002). Underemployment and relative deprivation among re-employed executives. Journal of Occupational and Organizational Psychology, 75, 453-471.

George, J., \& Jones, G. (1997). Experiencing work: Values, attitudes, and moods. Human Relations, 50, 393-416.

Hackman, J., \& Oldham, G. (1976). Motivation through design of work: Test of a theory. Organizational Behavior and Human Performance, 16, 250-279.

Isaksson, K., Johansson, G., Bellaagh, K., \& Sjoberg, A. (2004). Work values among the unemployed: Changes over time and some gender differences. Scandinavian Journal of Psychology, 45, 207-214.

Jackson, P., Stafford, E., Banks, M., \& Warr, P. (1983) Unemployment and psychological dristress in young people: The moderating role of employment commitment. Journal of Applied Psychology, 68, 525-535.

Johnson, W., Morrow, P., \& Johnson, G. (2002). An evaluation of a perceived overqualification scale across work settings. Journal of Psychology, 136, 425-441.

Jones, S.R. (1988). The relationship between unemployment spells and reservation wages as a test of search theory. Quarterly Journal of Economics, 103, 741-765.

Jöreskog, K.G., \& Sörbom, D. (2004). LISREL 8.5 User's reference guide. Chicago, IL: Scientific Software International. 
Kanfer, R., Wanberg, C., \& Kantrowitz, T. (2001). Job-search and employment: A personality-motivational analysis and meta-analytic review. Journal of Applied Psychology, 86, 837-855.

Kara, S., Kayis, B., \& O'Kane, S. (2002). The role of human factors in flexibility management: A survey. Human Factors and Ergonomics in Manufacturing, 12, $75-119$.

Kasser, T. (2002). The high price of materialism. Cambridge, MA and London: The MIT Press.

Kasser, T., \& Ryan, R. (1996). Further examining the American dream: Differential correlates of intrinsic and extrinsic goals. Personality and Social Psychology Bulletin, 22, 280-287.

Kernis, M., Brown, A., \& Brody, G. (2000). Fragile self-esteem in children and its associations with perceived patterns of parent-child communication. Journal of Personality, 68, 225-252.

Kline, R.B. (2005). Principles and practices of structural equation modeling (2nd edn.). New York: Guilford Press.

Knoop, R. (1994). Work values and job-satisfaction. Journal of Psychology, 128, 683-690.

Kristof-Brown, A., Zimmerman, R., \& Johnson, E. (2005). Consequences of individuals' fit at work: A meta-analysis of person-job, person-organization, persongroup, and person-supervisor fit. Personnel Psychology, 58, 285-342.

Leana, C., \& Feldman, D. (1995). Finding new jobs after a plant closing: Antecedents and outcomes of the occurence and quality of reemployment. Human Relations, 48, 1381-1401.

Lyubomirsky, S., \& Ross, L. (1997). Hedonic consequences of social comparison: A contrast of happy and unhappy people. Journal of Personality and Social Psychology, 73, 1141-1157.

Maynard, D.C., Joseph T.A., \& Maynard, A.M. (2006). Underemployment, job attitudes, and turnover intentions. Journal of Organizational Behavior, 27, 509536.

O'Brien, G., \& Feather, N. (1990). The relative effects of unemployment and quality of employment on the affect, work values and personal control of adolescents. Journal of Occupational Psychology, 63, 151-165.

Peiro, J., Garcia-Montalvo, J., \& Gracia, F. (2002). How do young people cope with job flexibility? Demographic and psychological antecedents of the resistance to accept a job with non-preferred flexibility features. Applied Psychology: An International Review, 51, 43-66.

Reilly, P. (1998a). Introduction: Flexibility for the individual, organization and society. European Journal of Work and Organizational Psychology, 8, 1-6.

Reilly, P. (1998b). Balancing flexibility: Meeting the interests of employer and employee. European Journal of Work and Organizational Psychology, 8, 7-22.

Rogelberg, S. (Ed.) (2002). Handbook of research methods in industrial and organizational psychology. Oxford: Blackwell Publishers.

Rokeach, M.J. (1973). The nature of human values. New York: The Free Press.

Ryan, R. (1995). Psychological needs and the facilitation of integrative processes. Journal of Personality, 63, 397-427. 
Satorra, A., \& Bentler, P.M. (1994). Corrections to test statistics and standard errors in covariance structure analysis. In A. von Eye \& C.C. Clogg (Eds.), Latent variables analysis: Applications for developmental research (pp. 399-419). Thousand Oaks, CA: Sage.

Schwartz, S. (1992). Universals in the content and structure of values: Theoretical advances and empirical tests in 20 countries. Advances in Experimental Social Psychology, 25, 1-65.

Sheldon, K., Ryan, R., Deci, E., \& Kasser, T. (2004). The independent effects of goal contents and motives on well-being: It's both what you pursue and why you pursue it. Personality and Social Psychology Bulletin, 30, 475-486.

Tregaskis, O., Brewster, C., Mayne, L., \& Hegewisch, A. (1998). Flexible work in Europe: The evidence and the implications. European Journal of Work and Organizational Psychology, 7, 61-78.

Van den Berg, P., \& van der Velde, M. (2005). Relationships of functional flexibility with individual and work factors. Journal of Business and Psychology, 20, 111-129.

Vandoorne, J., De Witte, H., \& Hooge, J. (2000), Werk in zicht: houding ten aanzien van arbeid en toekomstperspectief op de arbeidsmarkt [Work in sight: Attitude toward work and future perspective on the labour market]. In H. De Witte, J. Hooge, \& L. Walgrave (Eds.), Jongeren in Vlaanderen: gemeten en geteld. 12- tot 18- jarigen over hun leefwereld en toekomst (pp. 185-208). Leuven: Universitaire Pers Leuven.

Vansteenkiste, M., Lens, W., \& Deci, E.L. (2006). Intrinsic versus extrinsic goal contents in self-determination theory: Another look at the quality of academic motivation. Educational Psychologist, 41, 19-31.

Vansteenkiste, M., Lens, W., De Witte, H., \& Feather, N. (2005). Understanding unemployed people's job-search behaviour, unemployment experience and wellbeing: A comparison of expectancy-value theory and self-determination theory. British Journal of Social Psychology, 44, 1-20.

Vansteenkiste, M., Lens, W., Dewitte, S., De Witte, H., \& Deci, E.L. (2004). The "why" and "why not" of job-search behavior: Their relation to searching, unemployment experience, and well-being. European Journal of Social Psychology, 34, 345-363.

Vansteenkiste, M., Neyrinck, B., Niemiec, C., Soenens, B., De Witte, H., \& Van den Broeck, A. (2007). On the relations among work value orientations, psychological need satisfaction, and job outcomes: A self-determination theory approach. Journal of Occupational and Organizational Psychology, 80, 251-277.

Vansteenkiste, M., Ryan, R.M., \& Deci, E.L. (in press). Self-determination theory and the explanatory role of psychological needs in human well-being. In L. Bruni, F. Comim, \& M. Pugno (Eds.), Capabilities and happiness. Oxford: Oxford University Press.

Vansteenkiste, M., Simons, J., Lens, W., Sheldon, K.M., \& Deci, E.L. (2004). Motivating learning, performance, and persistence: The synergistic role of intrinsic goals and autonomy-support. Journal of Personality and Social Psychology, 87, 246-260.

Vansteenkiste, M., Soenens, B., \& Duriez, B. (2008). Presenting a positive alternative to materialistic strivings and the thin-ideal: Understanding the effects of extrinsic 
relative to intrinsic goal pursuits. In S.J. Lopez (Ed.), Positive psychology: Exploring the best in people. Westport, CT: Greenwood Publishing Company.

Vroom V. (1964). Work and motivation. New York: Wiley.

Warr, P. (1987). Work, unemployment, and mental health. Oxford: Clarendon Press.

\section{APPENDIX}

1. Work is the most important thing in life.

2. I prefer to be working, even if this implies a wage similar to welfare.

3. One should work to be part of the society.

4. It is not necessary to work in order to contribute.*

5. Even if I won the first prize in the lottery, I would prefer to continue in my job.

6. Working adds meaning to my life.

7. Accepting a job is better than being unemployed.

8. Being unemployed is about the worst thing that has happened to me.

9. Even if unemployment benefits were high, I prefer to work.

10. It is important to me to find employment

11. As an unemployed person, I feel I fall short.

12. I hate being unemployed.

13. Receiving unemployment benefits is a proper way to earn a living.*

14. I don't enjoy leisure time unless I have earned it.

* These items have been removed due to low factor loadings. 